\title{
THE IMPORTANCE OF ECONOMIC STRUCTURE EVOLUTION IN ACHIEVING PERFORMANCE - FROM AGRARIAN ECONOMY TO COMPETITIVENESS IN ROMANIAN ECONOMY ${ }^{1}$
}

\author{
Jean Vasile Andrei', Adrian Ungureanu ${ }^{3}$
}

\begin{abstract}
Summary
In terms of more increased integration and globalization of markets, risk diversification and exposure to external economic factors disturbing the structure of the national economy acquires a major role in alleviating and absorbing adverse effects on national economies are exposed. Starting from the reality that reducing disparities and achieving convergence criteria cannot be achieved except through the perspective of economic structures, the main objective of this research is the analysis of the importance of the economic structure in achieving functional requirements and competitive market economy, in the process of transition agrarian economy to a market economy in Romania, highlighting the main changes and effects that occurred in the past twenty-three years in the national economy, with a closer approach on agricultural structures.
\end{abstract}

Key words: agriculture, competitiveness, GDP, economic structure, inland economy.

JEL: $A 12, Q 10, M 20$

\section{Introduction}

Making functioning and highly competitive market economy in Romania is a major goal of a period marked by strong and sharp economic imbalances. The evolution of the national economy largely reflected the effects of a long process of reform and economic restructuring which had the main objective of making a strong centralized socialist economy to a market economy that works on the principles of economic democracy, being equally

1 This paper is supported by the Sectorial Operational Programme Human Resources Development (SOP HRD), financed from the European Social Fund and by the Romanian Government under the contract number SOP HRD/159/1.5/S/136077.

2 Andrei Jean Vasile, Ph.D., Assistant, Petroleum-Gas University of Ploiesti, Faculty of Economic Sciences, B-dul Bucuresti no. 39, 100680 Ploiesi, Prahova, Romania, Phone: +40 721146587 , E-mail: ajvasile@upg-ploiesti.ro

3 Ungureanu Adrian, Ph.D., Lecturer, Petroleum-Gas University of Ploiesti, Faculty of Economic Sciences, B-dul Bucuresti no. 39, 100680 Ploiesi, Prahova, Romania, Phone: +40 723561 211, E-mail: ungureanu adrian2001@yahoo.com.

EP 2014 (61) 4 (945-957) 
a sounding board for the frequent and sometimes very disarticulated reform measures that have contributed mostly to the economic environment-enhancing and rather more stressed economic imbalances. From this perspective, agriculture continued to play an important role in the national economy, becoming, as remarked in some specialized studies (Karp and Stefanou, 1993; Abele and Frohberg, 2003; Swinnen and Ciaian, 2008), net safety for a population with strong accents of rurality.

The findings of the literature confirm once again the difficulties in achieving the necessary conditions of a market economy. Thus Petrescu(2013) noted that "after 1990, the agricultural sector has encountered a sinuous phase of redefining and re-positing the national economy, the reality of the socialist period was decomposed to make room for new coordinates" (Petrescu, 2013, p. 36).

Although during the fourteen years of continuous transition Romania succeeded, after a period of more than seventeen years, to integrate into the European economic and social space, there are still imbalances in the national economy and the economic performance is modest. From a sectorial perspective, agriculture, although significantly reduced its contribution to GDP (Global Domestic Product), continued to influence significantly the macroeconomic results as it was remarked in some studies as (Ciutacu et al., 2014; Tegledi, 2011; Done et al., 2012).

In achieving the objectives, the present paper is structured on two major dimensions for understanding the transformations that marked the national economy in the shift of achieving the criteria of a functioning market economy. Thus in the first part of the paper we analyse the evolution of global GDP and GVA (Gross Value Added), but also in terms of structure, on the other hand is trying to explain some of the factors that accentuate the gaps between national and European space economy, trying to offer some explanations in this respect.

Regarding the importance of agriculture in the national economy were conducted numerous studies and most of them reveal the need for analysis and understanding of the role and impact that this economic sector owns both transition economies and in terms of alleviating the economic crisis. Such as notice (Dachin, 2011) agriculture, for some European countries is considered an industry, after a long process of grant and redistribution of public financial resources, which have direct and immediate effect a sustained increase in economic performance, becoming the highest competitive. On the other hand (Dropu, 2007) provides an image of Romanian agriculture, torn by the ancestral desire of land ownership and stubbornness of peasants to keep their identity, sometimes synonymous with love of land.

As it has been already observed (Andrei and Gheorghe, 2014; Done et al., 2012), agriculture is a branch with important significance to the national economy by mobilizing resources that it has and the major role it holds in the rural communities, for which it often constitutes the only branch of activity. Achieving an efficient economy in Romania depends on the way the national economic structures adapt to the demands for performance required by the operation of a competitive market economy, in the context of convergence with the European space. 
The high degree of ruralisation of the national economy can be an obstacle in compliance with the application requirements of European cultural and economic model, to which most we often try to relate. The gaps that still persist towards the European economic model, at least from the perspective of achieving a competitive agriculture, can represent starting points for increasing competitiveness by enhancing restructuring.

\section{The evolution of gross domestic product as effect of economic structures development}

Analyzing the Gross Domestic Product (GDP) evolution as a direct effect of of the economic structures development and restructuration represents a major challenge in case of a transitional economy as Romania economy is. For achieving responsible and predictive results the analysis was based starting from some literature studies as (Andrei et al., 2014; Zaharia and Zaharia, 2013; Done et al., 2012; Andrei and Untaru, 2012; Gheorghe, 2014; Arcand and Borodak, 2011).

In order to carrying out the research it was used mainly the official statists datasets from INS (2014a), INS (2014b), INS (2012) and INS (2008).

In modern economies knowing the level of macroeconomic outcome is not only an obligation for decision makers, but it especially requires choosing the most effective methods in construction, management and allocation of public funds towards those sectors that generate high added value. In this context the Gross Domestic Product (GDP) is one of the most used indicators for measuring macroeconomic results, although in the specialty literature there are increasingly highlighted the weaknesses and vulnerabilities in its measurement. At least in the case of Romania, the dimension of GDP is the subject of extensive discussion regarding sampling and margin of error in measuring this indicator. The GDP structure to achieve the highest level identify those sectors with functional and appropriate degree of competitiveness in the national economy.

Thus, if at the beginning of the transition period in Romania, in 1990, GDP was 857.9 billion lei nominal value, seventeen years later, in 2007, the year of integration of the national economy in the European Union, it reached a nominal value of 404.7 billion, which represented in terms of real calculation a growth of only $6.0 \%$ over the previous year, 2006. But analyzing annual variations in real GDP in Romania for the period 19902011, it can found that for twelve years it has recorded positive growth rates, from a low of $1.5 \%$ (1993), to a maximum of $8.5 \%$ (in 2004). In other years of the transition period, the annual percentage variation was negative, ranging from a low of $-12.9 \%$ (in 1991) to a value of $-1.2 \%$ in 1999. In Figure 1 it is showed the evolution of real GDP during 1990-2011. 
Figure 1. The evolution of real GDP in the period 1990-2011 (previous year $=100 \%$ )

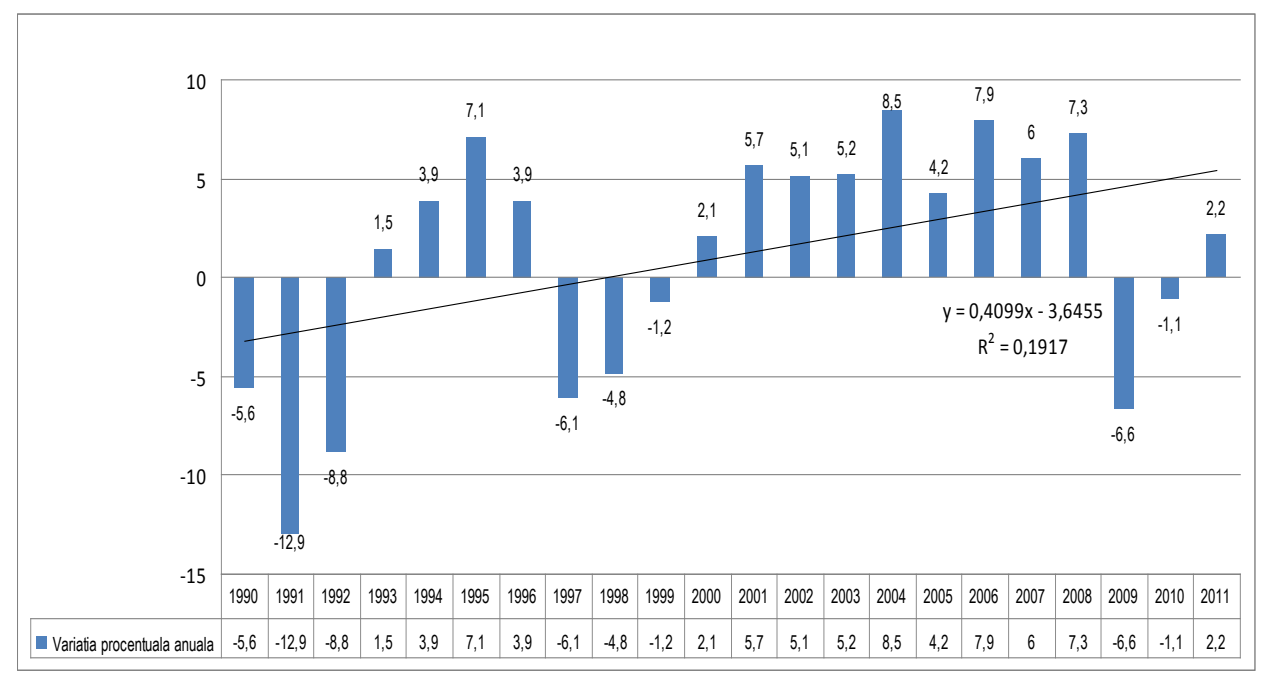

Source: authors` own computation based on INS (2012)

As it can be seen from the data presented in Figure 1, over the period 1990-2011 it can identify three major cycles of the evolution of real GDP, with their corresponding phases. Also as it is already remarked in literature (Anghelache, 2013; Ciutacu and Chivu, 2009a; INS, 2008; Dobrota, 1999), the first economic cycle (1990-1996) is shorter than the second (1997-2008). It can be said that over the period of analysis, the first cycle of transition to a functional market economy, in terms of the evolution of real GDP, had a period of seven years with a downward phase of three years (1990 -1992) and an upturn for four years (1993-1996) and the second cycle has twelve years all started with three consecutive years of economic decline (1997-1999), followed by a phase upward of nine years (2000-2008). The third cycle corresponds to the period of economic crisis and it is characterized by two consecutive years of decline (-6.6 in 2009 and -1.1 in 2010), followed by a slight recovery in 2011 when it recorded an increase of $2.2 \%$ in real terms (INS, 2014a). Table 1 presents the evolution of economic sectors contribution to gross domestic product in the period 1995-2012.

Table 1. The importance of economic sectors to GDP in Romania, 1995-2012 (\% in GDP)

\begin{tabular}{|l|l|l|l|l|l|l|}
\hline \multicolumn{1}{|c|}{ Activities } & $\mathbf{1 9 9 5}$ & $\mathbf{2 0 0 0}$ & $\mathbf{2 0 0 5}$ & $\mathbf{2 0 1 0}$ & \multicolumn{1}{|c|}{$\mathbf{2 0 1 1}$} & \multicolumn{1}{|c|}{$\mathbf{2 0 1 2}$} \\
\hline Agriculture, forestry and fishing & 17.97 & 10.83 & 8.41 & 5.70 & 6.52 & 4.88 \\
\hline Industry & 30.00 & 24.87 & 24.81 & 28.37 & 28.82 & 28.25 \\
\hline Construction & 6.28 & 5.16 & 6.89 & 9.12 & 8.07 & 8.57 \\
\hline Commerce and services & 2.18 & 4.88 & 3.95 & 3.40 & 3.40 & 3.55 \\
\hline Information and communication & 2.18 & 4.88 & 3.95 & 3.40 & 3.40 & 3.55 \\
\hline Financial intermediation and insurance & 6.88 & 3.98 & 2.02 & 2.23 & 2.51 & 2.45 \\
\hline Real estate activities & 7.26 & 7.31 & 7.48 & 8.83 & 8.41 & 8.19 \\
\hline Professional, scientific and technical activities & 1.90 & 2.41 & 2.95 & 4.72 & 5.57 & 6.18 \\
\hline Culture & 1.84 & 2.74 & 2.15 & 2.56 & 2.86 & 3.02 \\
\hline
\end{tabular}

Source: authors' analysis based on INS (2014a). 
From the data presented in the above table we can observe a general trend of increasing the share of contribution to the GDP of most economic sectors excepting agriculture and financial intermediation and insurance which recorded decreases of the contribution levels. The contribution of agriculture to GDP has declined significantly over the period.

In 2012, the GDP in nominal terms was 28,638,100,000 lei, returning 29.127 billion lei per capita. Thus if a comparison of the last two years for which no statistical data, in 2011 compared to 2010 , gross domestic product in real terms increased by $2.2 \%$, and GDP per capita increased by $2,5 \%$ and the overall national economy registered a slight recovery compared to the last two years of economic contraction (-6.6\% in 2009 compared to 2008, $-1.6 \%$ in 2010 compared to 2009), in 2012 it was showed an increase of $5.27 \%$ of GDP compared to 2011, while GDP / capita by $11.6 \%$.

In 2011, the evolution of GDP by sector had the following characteristics: services posted the largest contribution to GDP, or $43.5 \%$ of total (242,396.9 million); industry ranked second place, i.e. $28.9 \%$ of GDP (160,927.9 million); construction contributed $8.5 \%$ to GDP; agriculture, hunting, forestry and fishing contributed 6.6\% of GDP. In 2011, the gross added value recorded was 487,326.8 million and represented $87.5 \%$ of GDP.

In 2012 the contribution of agriculture was only 4.88\%, 17.97\% compared to 1995, being slightly higher than the branches that held relatively insignificant share in 1995. In Figure 2 it is showed the contribution of agriculture to GDP, GNI (gross national income) and GVA (gross value added).

Figure 2. The contribution of agriculture to the main result indicators (1995-2011)

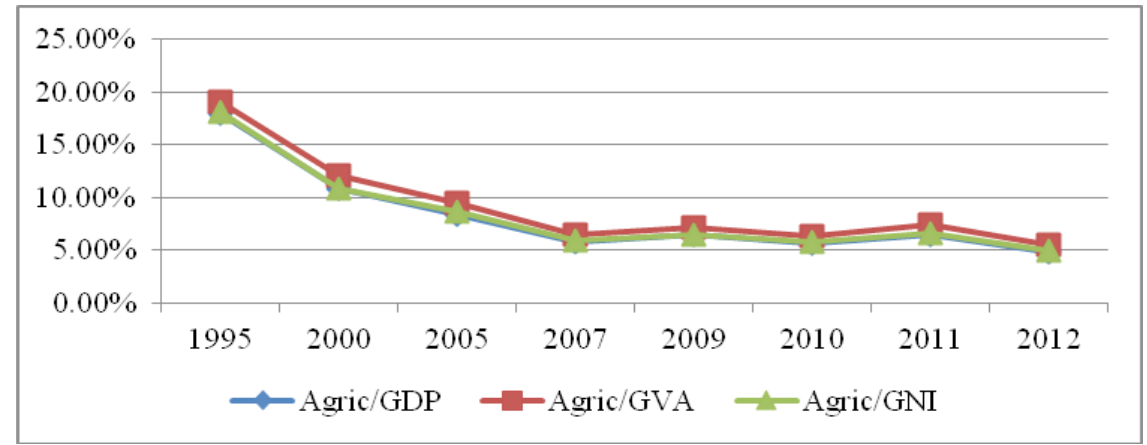

Source: authors based on INS (2014a)

Thus, if in 1995 the agriculture contributed with $17.97 \%$ to GDP, $19.7 \%$ to GVA and $18.14 \%$ to GNI, highlighting the importance that this economic sector has in the national economy, and also giving it strong agrarian transformations that occurred in massive restructuring of the national economy for integration into the community space, generated a rearrangement of national economic structures in order to reduce the structural gaps to the European model and increasing convergence towards the European space. In 2012, agriculture, yet has a relatively significant role to GDP, the values are significantly reduced, contributing with 4.88\% in GDP formation, 5.59\% in generating GVA and and 4.97\% in achieving GNI. 
From a general perspective, namely that of gross value added contribution to GDP during the transition to a market economy and achieve competitive terms and functionality, it can be seen that its level was significantly greater than the other components. Thus at the beginning of the transition process, namely in 1990, the gross value added in the national economic sectors contributed $91.9 \%$ to GDP and net taxes on products by $8.1 \%$. Thus in the same year for the national economy, namely in 2007, it can be seen that the share of taxes in GDP increased (from 11.1\% of GDP) to the detriment of GVA contribution to GDP. At the end of the review period, the share of taxes in GDP increased from 12.5\% out of GDP (in 2011). GVA was achieved through concerted contribution, but not identical to the three activity sectors: primary, secondary and tertiary, as it can be seen in Figure 3.

Figure 3. Main economic contribution to GVA formation in Romanian economy (1995-2011)

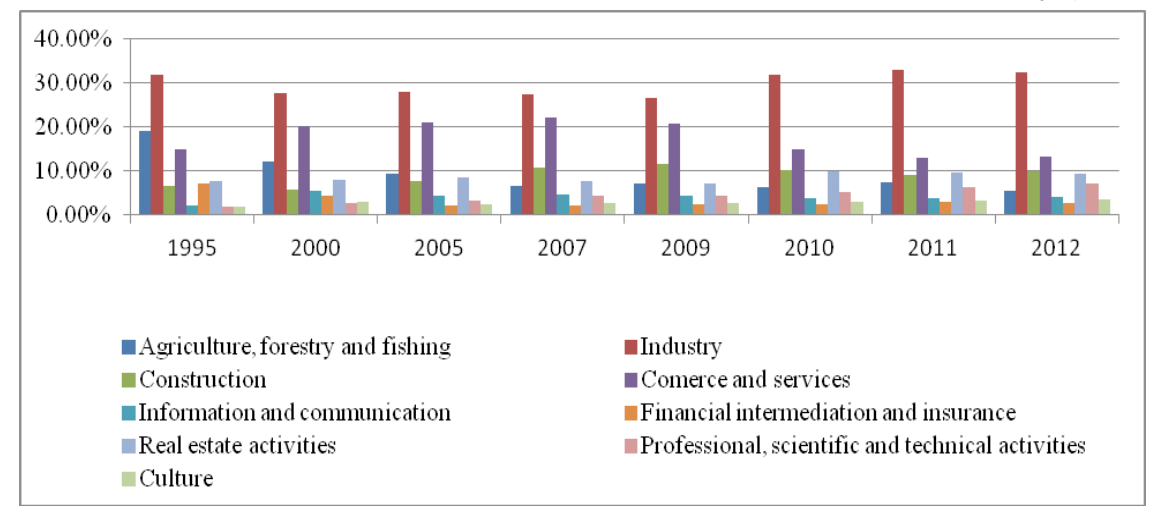

Source: authors` based on INS (2014a,b)

The GDP expressed at current prices, in terms of its creation in sectors, has undergone significant changes over the period. Expressed in USD or Euro current value is directly dependent on global supply indicators of changes if the exchange rate. In terms of value, according to the reference currency, the GDP in 1990 has been exceeded since 1998 (if the expression is the current Euro or USD).

Table 2. Global supply structure in current prices (in billion, 1990-2011)

\begin{tabular}{|l|c|c|c|c|c|c|c|c|c|}
\hline \multirow{2}{*}{$\begin{array}{l}\text { Year/ } \\
\text { Currency }\end{array}$} & \multicolumn{3}{|c|}{$\mathbf{1 9 9 0}$} & \multicolumn{3}{c|}{$\mathbf{2 0 0 7}$} & \multicolumn{3}{c|}{2011} \\
\cline { 2 - 11 } \\
\cline { 2 - 5 } & 857.9 & 31.3 & 39.8 & 404.7 & 121.3 & 166.0 & 556.7 & 131.6 & 182.6 \\
\hline GVA & 788.1 & 28.7 & 36.6 & 359.6 & 107.8 & 147.5 & 487.3 & 115.2 & 159.9 \\
\hline $\begin{array}{l}\text { Primary } \\
\text { sector }\end{array}$ & 187.1 & 6.8 & 8.7 & 26.9 & 8.0 & 11.0 & 36.4 & 8.6 & 11.9 \\
\hline $\begin{array}{l}\text { Secondary } \\
\text { Sector }\end{array}$ & 393.6 & 14.3 & 18.3 & 131.8 & 39.5 & 54.1 & 208.4 & 49.3 & 68.4 \\
\hline $\begin{array}{l}\text { Tertiary } \\
\text { Sector }\end{array}$ & 207.4 & 7.6 & 9.6 & 200.9 & 60.2 & 82.4 & 242.3 & 57.3 & 79.5 \\
\hline Others & 69.8 & 2.5 & 3.2 & 45.1 & 13.5 & 18.5 & 69.4 & 16.4 & 22.8 \\
\hline
\end{tabular}

Source: processing based on the author's own computation from TEMPO (INS 2012) https:// statistici.insse.ro/shop/index.jsp?page $=$ tempo3\&lang $=$ ro\&ind $=$ CON103A 
Having into account the official datasets (INS, 2008, INS, 2012) in 1990, the primary sector activities, consisting of activities in the fields of agriculture, hunting, forestry, fishing and fish farming contribute 6.8 billion Euro, respectively, 8.7 billion USD to GDP. In 1995 and 2000, the contribution of this sector has considerably reduced not only value but also as a share of GDP. In 2007, the 8.0 billion or 11.0 billion represented only $6.6 \%$ contribution of the primary sector to GDP. Expressed in USD, gross value added in the primary sector increased in 2007 compared to 1990 by $26.4 \%$ and $17.6 \%$ when expressed in EUR.

Explanation of gross added value growth in the primary sector in 2007 is simple: depreciation of the exchange rate of two currencies: Euro and USD, more pronounced when the US currency. In fact, intermediate consumption increased for years due to the accelerated growth of prices for agricultural imports, but also due to the reconstruction of flood and storm disaster, crop yields modest and low efficiency of livestock have negatively affected agricultural activities.

Although agriculture is almost a completely privatized economic sector, however, agricultural yields are much lower than in 1990, which determined the reduction percentage contribution of this sector to GDP. At the same time, one cannot omit the fact that the mechanisms of transfer of value added in agriculture did not favour this sector. The added value of this sector is transferred to the processing and marketing of agricultural products. The secondary sector's share in GDP has not exceeded in any year the amount recorded in 1990. However, it can be seen that, expressed in EUR or USD currency, in 2007, the sector has contributed 39.5 billion EUR, respectively 54.1 billion USD to GDP, and 49.3 billion EUR in 2011, 68.4 billion USD, respectively.

The evolution of the gross added value in industry is the result of limiting activities in most industrial sub-sectors, the delay in restructuring and the low economic efficiency compared to the potential of this sector.

In 1990, the tertiary sector produced only 7.6 billion EUR, respectively 9.6 billion USD out of total GDP. The value added in this sector has increased steadily. In this context, the development of our country's economy became increasingly dependent on this area. In 2011, the service sector managed to produce 57.3 billion EUR, respectively 79.5 billion USD out of total GDP. As a result of the undertaken analysis, we can say that we are witnessing a continuous process of tertiary economic activities in Romania. Obviously it should reflect a normal trend of structural changes in the economy.

In the period 1990-2011, the tertiary trend was not a natural consequence of high productivity in the primary and secondary sectors (in some years), due to which, naturally, a reorientation of saved resources from the service sector becomes possible, but rather the expression of a process of economic de-structuring of the activity of large companies, mainly industrial and the capital redirection to more profitable activities for investors, respectively the sectors that allow a higher speed of capital rotation. 


\section{The evolution of labour resources in the Romanian economy from a sectoral perspective}

After a continuous growth recorded in 2005-2008, since 2009 the employment began to decline, reaching in 2011 the lowest recorded value (9.138 thousand). Among the employed people, 55.0\% are men. Until 2002, most employment force was from rural environment, respectively. Since 2003, most of the employed population resides in urban areas, 55.5\% respectively in 2011 .

The reform and restriction of the economic system and the Romanian economy was accompanied by significant reductions in the number of staff and employees, and the changing of sectorial distribution of labour force, due to weaker employment rate of labour resources from $82.0 \%$ in 1990 to $63.0 \%$ in 1999 and $62.8 \%$ in 2011 . As it had been stated (Bleahu, 2004), in 2002, the number of employed non-agricultural rural population was identical to that recorded in the year 1993 and two times lower than the values recorded in 1996.

The structure of employment by sectors of the national economy, changes that have occurred since 1989 at the macroeconomic level, produced heavy industry restructuring, which caused a decrease in employment, rising unemployment has caused a shift industrial population to agricultural activities. Besides the two major changes, the dynamic services sector has allowed the reinstatement of a large part of the working population.

Although it strives a lot, Romania still lags behind other EU countries, both in terms of socio-economic development and labour productivity. One of the main causes refers to the significant discrepancies from the structural point of view, the distribution of labour in the three main sectors of the Romanian economy.

Table 3. The evolution of the population structure by sector in Romania (in \%)

\begin{tabular}{|l|c|c|c|c|c|c|c|}
\hline \multicolumn{1}{|c|}{ Economic sector } & $\mathbf{2 0 0 0}$ & $\mathbf{2 0 0 5}$ & $\mathbf{2 0 0 7}$ & $\mathbf{2 0 0 8}$ & $\mathbf{2 0 0 9}$ & $\mathbf{2 0 1 0}$ & $\mathbf{2 0 1 1}$ \\
\hline $\begin{array}{l}\text { Primary sector (agriculture, hunting, } \\
\text { forestry, fishing, fish farming) }\end{array}$ & 41.5 & 31.9 & 29.5 & 28.7 & 29.0 & 28.7 & 29.1 \\
\hline $\begin{array}{l}\text { Secondary sector (industry, } \\
\text { construction) }\end{array}$ & 27.3 & 29.0 & 31.4 & 31.4 & 30.0 & 28.5 & 28.2 \\
\hline Tertiary sector (services) & 31.2 & 39.1 & 39.1 & 39.9 & 41.0 & 42.8 & 42.7 \\
\hline Total & 100.0 & 100.0 & 100.0 & 100.0 & 100.0 & 100.0 & 100.0 \\
\hline
\end{tabular}

Source: author's own processing based on TEMPO online https://statistici.insse.ro/shop/index.jsp?pag e=tempo3\&lang $=$ ro\&ind $=$ CON103A and INS (2012).

Regarding inland economy, there has been noticed a slight increase in employment in the tertiary sector, from $31.2 \%$ in 2000 to $42.7 \%$ in 2011 , the beginning of growth is reflected in the slight increase in employment in industry and services. There is a growth of $11.5 \%$ in the tertiary sector in 2011 compared to 2000, this increase being due to employment in a proportion of increasingly large services. Although in the case of agriculture notice a dramatic reduction in the labour force, from $41.5 \%$ in 2000 to $29.1 \%$ in 2011 , it is one whole with relatively positive meanings, implying a reorientation of labour resources to 
other absorbent economic sectors, as we have previously shown to services, which would bring in terms of employment, the national economy with the European economic and social model.

The relative parity of the evolution of population structure between agriculture and industry raises a question mark, at least in terms of economic structures. Thus the national economy has still a significant degree of dependence on agriculture, this sector still mobilizes labour resources, at least compared to those mobilized in the industry. But the effect is felt in productivity per hour worked. In Figure 4 it is shown the evolution of Labour productivity per hour worked in the period 2000-2011.

Figure 4. The labour productivity per hour worked in Romania (2000-2011)

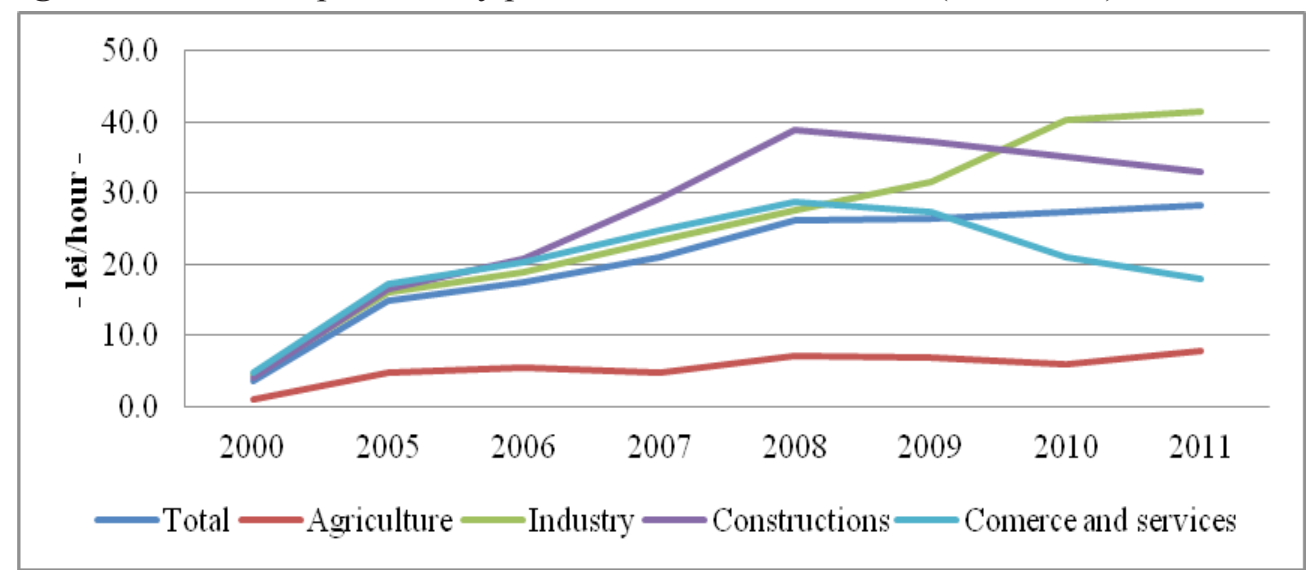

Source: author's analysis based on INS (2012)

The labour productivity is a significant indicator in the assessment of overall economic performance. During the analysed period it was showed an increase in the overall level of productivity from 3.6 lei/hour worked in 2000 to 28.4 lei/hour worked in 2011, which means an increase of 7.8 times the level of productivity in an interval of eleven. Although it mobilizes significant percentage equal to industry, the agriculture maintains a high productivity gap to it. The labour productivity in agriculture, although it increased 7.38 times over the analysed period from 1.0 lei/hour worked in 2000 to 7.7 EUR/hour worked in 2011 , represents only $18.5 \%$ of the 2011 labour productivity per hour worked levels industry in 2011. If in 2000 labour productivity per hour worked in agriculture represented $23.76 \%$ of the level registered in industry, $25.24 \%$ of that of the construction and $21.84 \%$ in commerce and services at end of period, in 2011 it represented $18.51 \%$ of the labour productivity in industry, $23.26 \%$ of the labour productivity in construction and $42.78 \%$ of the level of trade and services.

The productivity gaps in terms of productivity per hour worked labour are maintained throughout the entire analysed period what constitutes a plausible explanation in explaining productivity gaps between national and European economy. The domestic economic structure reflects the need for a major restructuring of sectors in terms of ensuring a degree of increased competitiveness. As for the Romanian economy, although it has a major EP 2014 (61) 4 (945-957) 
role, a lot oversized, agriculture fails in providing a high level of economic performance, managing increasingly political role of social protection for the population.

\section{The evolution of the employee's number as economic structures reconfiguration}

The average number of employees decreased in 2011 by 27.3 thousand persons compared to the previous year $(4,376.0$ thousand) as a result of personnel fluctuations and financial difficulties in most of the economic activities. The most pronounced declines were registered in the activities such as: health and social work, public administration and education. The distribution of employees by economic sectors in 2011 shows that $61.1 \%$ are in services (tertiary) 0.7 percentage points lower than in 2010 and 0.6 percentage points higher than in 2009. In the secondary sector (industry + construction) there worked $36.6 \%$ of total employees, 0.6 percentage points more than in 2010 and 0.6 percentage points less than in 2009 .

The share of employees who worked in agriculture (primary sector) was only $2.3 \%$, up 0.1 percentage points from the previous year and stopped at the level of 2009. As it has been found in the specialty literature (Rusu and Florian, 2003), although high percentage of the workforce employed in agriculture is a phenomenon contrary to evolution towards a market economy, in Romania's case, it is part of the national custom, the effect of a too long transition period, with at least questionable results. On other studies (Done et al., 2012; Ciutacu and Chivu, 2009b)

The private sector is the engine of the Romanian economy, absorbing most of the employed labour force. In 2011, the share of private sector employees was $66.2 \%$, up from $2.4 \%$ in 2010. Thus over 21 years (1990-2011) the economic restriction led to cutting more than 3.8 million salaried jobs (about 8.1 million in 1990 to 4,300,000 in 2011). Most affected people are from industry (2.6 million), agriculture ( 0.65 million), transport ( 0.41 million), construction ( 0.37 million). The number of employees increased in trade ( 250 thousand), public administration (116 thousand), financial intermediation $(48,000)$, and health (about 23 thousand).

Table 4. Evolution of the number of employees per branch (in 000, 1990-2011)

\begin{tabular}{|l|c|c|c|c|c|c|c|}
\hline \multirow{2}{*}{\multicolumn{1}{c|}{ Economic sector }} & \multirow{2}{*}{$\begin{array}{c}\text { Total number } \\
\text { (thousand/ } \\
\text { persons) } \mathbf{1 9 9 0}\end{array}$} & $\begin{array}{c}\mathbf{1 9 9 0 -} \\
\mathbf{1 9 9 5}\end{array}$ & \begin{tabular}{c}
$\mathbf{1 9 9 6} \mathbf{2 0 0 0}$ \\
\cline { 5 - 9 }
\end{tabular} & $\begin{array}{c}\mathbf{2 0 0 1}- \\
\mathbf{2 0 0 5}\end{array}$ & $\begin{array}{c}\mathbf{2 0 0 6} \\
\mathbf{2 0 0 8}\end{array}$ & $\begin{array}{c}\mathbf{2 0 0 9}- \\
\mathbf{2 0 1 1}\end{array}$ & $\begin{array}{c}\text { Total } \\
\mathbf{1 9 9 0}- \\
\mathbf{2 0 1 1}\end{array}$ \\
\hline TOTAL OF EMPLOYEES & 8.156 & -1.996 & -1.537 & -64 & 487 & -697 & -3.807 \\
\hline Agriculture, forestry and fishing & 762 & -259 & -307 & -52 & -29 & -7 & -654 \\
\hline Industry & 3.846 & -1.231 & -742 & -201 & -102 & -347 & -2.623 \\
\hline Constructions & 704 & -261 & -127 & 32 & 105 & -124 & -375 \\
\hline Trade & 508 & 152 & -92 & 109 & 177 & -96 & 250 \\
\hline Hotels and restaurants & 195 & -80 & -31 & 6 & 28 & -10 & -87 \\
\hline $\begin{array}{l}\text { Transport, storage and } \\
\text { communications }\end{array}$ & 724 & -208 & -146 & -51 & 23 & -29 & -411 \\
\hline Financial brokerage & 38 & 29 & 4 & 6 & 30 & -21 & 48 \\
\hline
\end{tabular}




\begin{tabular}{|l|c|c|c|c|c|c|c|}
\hline \multirow{2}{*}{ Economic sector } & \multirow{2}{*}{$\begin{array}{c}\text { Total number } \\
\text { (thousand/ } \\
\text { persons) } \mathbf{1 9 9 0}\end{array}$} & $\begin{array}{c}\mathbf{1 9 9 0 -} \\
\mathbf{1 9 9 5}\end{array}$ & $\begin{array}{c}\mathbf{1 9 9 6 -} \\
\mathbf{2 0 0 0}\end{array}$ & $\begin{array}{c}\mathbf{2 0 0 1 -} \\
\mathbf{2 0 0 5}\end{array}$ & $\begin{array}{c}\mathbf{2 0 0 6}- \\
\mathbf{2 0 0 8}\end{array}$ & $\begin{array}{c}\mathbf{2 0 0 9} \\
\mathbf{2 0 1 1}\end{array}$ & $\begin{array}{c}\text { Total } \\
\mathbf{1 9 9 0} \\
\mathbf{2 0 1 1}\end{array}$ \\
\hline Real Estate & 391 & -196 & -18 & 63 & 135 & -4 & -20 \\
\hline Public Administration and Defence & 80 & 50 & 18 & 19 & 49 & -20 & 116 \\
\hline Education & 368 & 59 & -20 & -26 & 13 & -30 & -4 \\
\hline Health and social care & 316 & 12 & -23 & 16 & 35 & -17 & 23 \\
\hline Other activities & 224 & -63 & -53 & 15 & 23 & -1 & -79 \\
\hline
\end{tabular}

Source: author's own calculations on the basis of INS (2014a,b)

In the period, 1990-2011, only in the subinterval 2006-2008, the evolution trend of the total number of employees was positive, the number increased by about 487,000 people; the industry and agriculture showed negative trends these years (the number of employees in agriculture decreased by 29,000 and 102,000 people in the industry). Referring to the high degree of working population in agriculture, especially after 1990 (Mihailescu, 2005) notes that this is the result of economic restructure that contributed to the reorientation of the farming population, the inability to work in the other economic sectors, which are in decline generated by a chaotic economic reform.

\section{Conclusions}

The analysis of the evolution of Romanian economy in terms of economic structures represents a significant step in understanding the mechanism and determinants in ensuring convergence with the European economic model. The agriculture has a role in achieving massive influential Romanian macroeconomic performance as one of the major economic sectors that mobilize human resources.

In Romania's case, the high degree of rurality makes agriculture play a pivotal role in the rural communities, providing not only a standard of living for the rural population for which production is mostly intended consumption, but the support in mitigating the effects of transition to a market economy. Although overall levels showed an improvement in outcome macroeconomic indicators and national economic structures, transformations that marked the national economic system in the transition to a functional market economy and highly competitive, are still not complete, emphasizing the need for compliance to the needs of European economic and social model.

\section{Literature}

1. Abele, S., Frohberg, K. (2003): Subsistence Agriculture in Central and Eastern Europe: How to Break the Vicious Circle?, Institute of Agricultural Development in Central and Eastern Europe, vol. 22, Institut für Agrarentwicklung in Mittel und Osteuropa (IAMO), Saale, Germany. 
2. Andrei, J. V., Eftimie, M., Matei, M.(2014):The role of Romanian farms in valuing the inland agricultural potential, Journal of Food, Agriculture \& Environment, vol. 12, no. 1, pp. 1532-1535.

3. Andrei, J. V., Untaru, M. (2012): Through Common Agricultural Policy Reforms: A Short Analysis, International Journal of Sustainable Economies Management, vol. 1, no. 3, pp. 32-40.

4. Andrei, J. V., Gheorghe, P. H. (2014): Economy in Romania and the Need for Optimization of Agricultural Production Structures, Peter Lang GmbH, Frankfurt am Main, Germany.

5. Anghelache, C. (2013): Romania 2013, Starea economica sub povara efectelor crizei, Editura Economica, Bucharest, Romania.

6. Arcand, J. L., Borodak, D. (2011): Explaining Productivity Differentials in Eastern European Agriculture: Efficiency or Class Structure?, CERDI-CNRS, Université d'Auvergne, France, retrieved from: https:/halshs.archives-ouvertes.fr/file/index/ docid/564567/filename/2006.12.pdf, [07.09.2014].

7. Bleahu, A. (2004): O perspectivă istorică asupra sectorului neagricol din mediul rural, Calitatea Vieții, vol. 1-2, pp. 85-95.

8. Ciutacu, C., Chivu, L. (2009a): New System To Follow Up The Unemployed In BelgiumRomanian Perspective, Romanian Journal of Economics, Institute of National Economy, vol. 28, no. 1(37), pp. 102-112.

9. Ciutacu, C., Chivu, L. (2009b): About Deficit Management In The Conditions Of Market Integration And Globalization, Annals of Faculty of Economics, University of Oradea, Faculty of Economics, vol. 1, no. 1, pp. 21-32.

10. Ciutacu, C., Chivu, L., Andrei, J. V. (2014): Similarities and Dissimilarities between the EU Agricultural and Rural Development Model and Romanian Agriculture.

Challenges and Perspectives, Land Use Policy, retrieved from: http://dx.doi. org/10.1016/j.landusepol.2014.08.009

11. Dachin, A. (2011): Contribuții ale agriculturii la fluctuațiile economice în România, Economie teoretică şi aplicată, vol. 18, no. 1(554), pp. 154-165.

12. Dobrota, N. (1999): Dictionary of Economics, Editura Economica, Bucharest, p. 99.

13. Done, I., Chivu, L., Andrei, J. V., Matei, M. (2012): Using Labor Force and Green Investments in Valuing the Romanian Agriculture Potential, Journal of Food, Agriculture \& Environment, vol. 10, no. 3-4, pp. 737-741.

14. Dropu, C. (2007): Agricultura şi politicianismul. Un secol de politică agrară în România 1907-2007, Iaşi: Sedcom Libris, Romania, p. 523.

15. Gheorghe, P. H. (2014): Labor Market Regulation and the Shadow Economy, Economics, Management and Financial Markets, vol. 9, no. 3, pp. 110-115.

16. INS (2008): Evoluția economico-socială a României în anul 2007, Bucharest, March 2008, Conference press, National Institute of Statistics, Bucharest, Romania.

17. INS (2012): Romania in figures: 2008-2011, National Institute of Statistics, Bucharest. 
18. INS (2014a): Anuarul Statistic al României. Serie de date 1990-2013, National Institute of Statistics, Bucharest, Romania.

19. INS (2014b), National Institute of Statistics, Bucharest, online database, available at: https://statistici.insse.ro/shop/index.jsp?page=tempo2\&lang=ro\&context $=15$

20. Karp, L. S., Stefanou, S. (1993): Domestic and Trade Policy for Central and East European Agriculture, Working Paper 93-7, No. 51110, International Agricultural Trade Research Consortium, retrieved from: http://purl.umn.edu/51110, [07.09.2014].

21. Mihăilescu, I. (2005): Factori de risc în evoluția mediului rural din România, Sociologie Românească, no. 3-4, pp. 5-36.

22. Petrescu, C. (2013): Organizatiile colective ale proprietarilor de terenuri agricole si forestiere. Profil, evolutie, tendinte, Iasi: Polirom, Romania.

23. Rusu, M., Florian, V. (2003): Rural Space and Rural Development in Romania, European Rural Development Network Studies, Rural Areas and Development, no. 1, pp. 39-55.

24. Swinnen, J. F. M., Ciaian, P. (2008): Growth, Competitiveness and Convergence in Romanian Agriculture, Agricultural Economics and Rural Development, vol. 5, no. 3-4, pp. 143-160.

25. Tegledi, M. A. (2011): Ways and Instruments of Accomplishing the Regional Policy Romanian Sustainable Development Strategy 2000 - 2025, Petroleum-Gas University of Ploiesti Bulletin, Economic Sciences Series, vol. LXIII, no. 3, pp. 96-104.

26.Zaharia, C., Zaharia, I. (2013): The Impact of the Economic Crisis in the Eurozone, Economics, Management, and Financial Markets, vol. 8, no. 2, pp. 192-197. 